\title{
QUANTUM OF BUILDING DEMOLISHED DEBRIS ASSOCIATED WITH URBAN ROAD CONSTRUCTION IN GOMBE CITY, NIGERIA
}

\author{
Bashir Usman Mohammed ${ }^{1 *}$, Dr. S. J. Dukku², Suleiman Shehu ${ }^{3}$ \\ ${ }^{1}$ Department of Architecture, Faculty of Environmental Technology, Abubakar Tafawa \\ Balewa University Bauchi, Nigeria. Emal: umbashir0@gmail.com \\ ${ }^{2}$ Department of Urban and Regional Planning, Faculty of Environmental Technology, \\ Abubakar Tafawa Balewa University Bauchi, Nigeria. Email: sanijibirdukku@gmail.com \\ ${ }^{3}$ Department of Quantity Surveying, Faculty of Environmental Technology, Abubakar \\ Tafawa Balewa University Bauchi, Nigeria. Email: ssuleiman088@gmail.com
}

\begin{abstract}
Cite this article:
Bashir U.M., Dukku S. J. , Suleiman S. (2021), Quantum of Building Demolished Debris Associated with Urban Road Construction in Gombe City, Nigeria. African Journal of Environment and Natural Science Research 4(3), 1-11. DOI: $10.52589 / A J E N S R-$ SAFEXNK8.
\end{abstract}

\section{Manuscript History \\ Received: 2 June 2021 \\ Accepted: 25 June 2021 \\ Published: 6 July 2021}

Copyright $\odot 2020$ The Author(s) This is an Open Access article distributed under the terms of Creative Commons AttributionNonCommercial-NoDerivatives 4.0 International (CC BY-NC-ND 4.0 ), which permits anyone to share, use, reproduce and redistribute in any medium, provided the original author and source are credited.
ABSTRACT: Demolition activity is deeply embedded in the urban system. In recent times, infrastructural development in Nigeria's major cities has led to increase in road construction activities associated with demolition of hundreds of houses from which millions of tons of Demolition Waste have been generated. However, it is widely reported in many studies globally that demolition debris is such waste that can be re-used. Though, this is not the case in Gombe due to paucity of information on its composition, size and quantities. Hence, the objective of this study is to determine the volumetric composition of generated demolition debris in Gombe City with a view to knowing the potential quantities available for re-use. The study used both qualitative and quantitative design approach. A simple random sampling technique was employed to select 13 roads which were subdivided in to Lot $1(8.33 \mathrm{~km})$ and Lot $2(15.04 \mathrm{~km})$ and the period of 2011-2014 was considered for the study. Primary data kept by actors and authorities for the compensation assessment which do not refer to demolition debris quantities were used as the bases for extraction of quantities. Handheld (GPS) instrument was used in establishing coordinates; photographs were taken from different locations showing demolition activities taking place and composition of different materials debris. Results revealed that a total of 1,271 structures were evaluated after partially or fully demolished for street widening and/or to pave way for new road construction, in addition a total volume of $129,993.57 \mathrm{~m}^{3}$ of Demolished Debris was generated which composed of $10.00 \%$ Concrete, $60.30 \%$ Sandcrete and $29.69 \%$ clay/mud. In conclusion, there exist huge quantities of building demolition debris from street widening and/or new road construction in Gombe city which can be put in to re-use as a component of urban road construction, where properly managed will go a long way to reducing environmental adverse effect due to excessive exploitation for new material.

KEYWORD: Composition, Construction, Demolition, Debris, Road, Quantity, Gombe 


\section{INTRODUCTION}

Demolition activity is deeply embedded in the urban system. It is seen as a barometer for economic activity, meaning when demolition occurs it is usually a sign of on-going growth, expansion and renewal (Richard \& Michael, 2006). It has been argued convincingly that there is a strong indication that demolition waste handling and management is the new challenging issue faced by many countries all over the world (Asif \& Matouq, 2013). In addition, Agamutu (2008) and Calhoun (2012) observed that data is not widely available for construction and demolition waste in many countries around the globe. In recent times, infrastructural development in Nigeria's major cities has led to the increase in road construction activities most noticeably in the state capitals and local government headquarters. Associated with this activity has been the demolition of hundreds of houses from which millions of tons of Demolition Waste have been generated. Thus, Daily Trust Newspaper of January 1, 2014 reported that, "Nigerians are familiar with waste of any kind, but when professionals talk about Construction and Demolition Debris (CDD), not many devote special attention to it because-waste is waste in Nigerian parlance". As such the quantity of construction demolition debris generated in the country is not known. By contrast, the quantity of waste generated is well documented in developed countries like USA, Japan, Germany, UK etc. Gombe is a fast-growing city in the North Eastern Part of Nigeria, with massive transformation of infrastructure. There has been considerable construction of new roads as well as street widening associated with large amounts of money as compensation for demolition of the identified buildings. However, it is reported widely in many studies globally that demolition debris is such waste that can be re-used. Though, this is not the case in Gombe due to paucity of information on its composition, size and quantities. Hence, the objective of this study is to determine the volumetric composition of generated demolition debris in Gombe City with a view to know the potential quantities available for re-use as base materials for road construction in Gombe city is timely.

\section{LITERATURE REVIEW}

The construction industry has been identified as the largest exploiter of both the renewable and non-renewable resources (Uher, 1999). It affects the environment in different ways; firstly, it consumes natural resources (both renewable and non-renewable) to produce the built environment, and secondly, it generates waste in the process of transforming the capital and natural resources (Ofori, 2010). Today's approach to creating cities, neighborhoods, building and infrastructure is a source of perceived negative effects on the natural environment and consequently on the economy and the community.

Studies carried out by Nunes K.R.A., Miller, C,F., Valley, R. and Neves ,C (2006) indicated that Demolition Debris represent the second largest component of material's waste stream just behind Municipal Solid Waste. Construction demolition debris is bulky, heavy and is mostly unsuitable for disposal by incineration or composting (Villas, 2007). According to the American Demolition Association and Organizations for the Demolition Industry in the United State and Canada was estimated that approximately $75 \%$ out of this composition is demolition debris. Similarly, Danish Environmental Protection Agency (DEPA) in 2003 established that of the total waste generated from construction and demolition in Denmark, $70 \%-75 \%$ was from demolition activity. In Japan also, $75 \%$ of demolition debris was 
generated from the total Construction and Demolition Debris in 2000, making demolition debris the highest component of Construction and Demolition Debris in most industrialized countries. Demolition debris is heterogeneous combination of various building materials such as aggregate, wood, sandcrete, paper, glass etc., these types of wastes results from the demolition of existing structures which were done intentionally like in renovation and remodeling works or unintentionally due to natural catastrophes such as earthquakes, floods, hurricanes etc., the components of demolition waste and its quantities depends primarily on the types and age of the being demolished as well as the materials used for its construction and the demolition technique followed (El- Haggar, 2007)

Basically, in Nigeria, infrastructural development such as roads within the urban built environment has seen the demolition of thousands of buildings in Nigeria (George, 1997). For example, In Akwa Ibom state, the conversion of single carriage ways to double carriage ways and the construction of roads networks across the 31-local government of the State (Akaninyene, 2012) generated demolition waste from demolished buildings. Daily Trust Newspaper of March 21, 2016 reported that, in 2012, over three thousand have been earmarked for demolition at Bassa Jiwa village, Airport Road Abuja and, about 500 housing estate units were demolished in the Federal Capital Territory, Abuja for development without approval (Falaki, Akanghe \& Ayinde, 2013). In Gombe state, it has been observed that between 2011 and 2014 thousands of buildings were earmarked and partially or fully demolished in Gombe city for the provision of road infrastructure, and billions of Naira was expended as compensation from the exercise and large volume of debris was generated.

\section{MATERIALS AND METHOD}

Gombe is the capital city of Gombe state, Nigeria and has an estimated population of 261,536 people (NPC, 2006). With a landmass area has an area of $52 \mathrm{~km}^{2}$ and situated between latitude $10^{0} 30^{\mathrm{I}}$ and $10^{0} 30^{1} \mathrm{~N}$ and longitude $11^{0} 00^{1}$ and $11^{\circ} 30^{\mathrm{I}} \mathrm{E}$ of the Greenwich meridian with two distinct climates, the dry season (November-March) and the rainy season (AprilOctober) with an average rainfall of $850 \mathrm{~mm}$. throughout the month of May daytime temperatures reach high of $40^{\circ} \mathrm{c}$, at night average minimum temperatures drop down to around $25^{\circ} \mathrm{c}$. This is not unconnected with the absence of vegetative cover to regulate the temperature. The average daily relative humidity for May of the same month is around $35 \%$.

The study is mixed type in its methodology, with both qualitative and quantitative as bases. Time horizon of the study indicated longitudinal that observed the phenomena over a chosen periods of three constitutional tenure of the leadership of Gombe State. A simple random sampling technique was employed to select 13 no. road which were sub-divided in to Lot 1 $(8.33 \mathrm{~km})$ and Lot $2(15.04 \mathrm{~km})$ for the period of 2011-2014 were considered for the study. Primary data kept by actors and authorities for the compensation assessment which do not refer to demolition debris quantities were used as the bases for extraction of quantities. Handheld (GPS) instrument was used in establishing coordinates; photographs were taken from different locations showing demolition activities taking place and composition of different materials debris. Recording and evaluation of primary data for the estimation of the quantities of debris in Gombe city was based on the appropriate scheme for the management of demolition debris. As such, the quantity was determined using acceptable already prepared document for the compensation of marked structures for the evaluation of quantities using 
Microsoft excels, through: Delineation of the area covered by the debris estimate; Dividing the area to differentiate sub-areas of dominant debris types; and Computation of the Demolishing Debris on a Street by street basis. Data analysis: Quantity of demolition debris was first extracted from the acquired primary data and composition of materials calculated in volume using Microsoft excel. The calculations were carried out using a mathematical model developed by FEMA Working Team, (2010) which was based on the following equation:

$\frac{\mathbf{L}(\mathbf{f t}) \mathbf{X} \mathbf{W}(\mathbf{f t}) \mathbf{x}(\mathbf{f t}) \times \mathbf{0 . 3 3}}{27}=\mathbf{C Y} \ldots \ldots($ Equ. 1$)$

"Equation 1 was modified to metric unit as thus,

$$
\frac{\mathbf{L}(\mathbf{m}) \times \mathbf{W}(\mathbf{m}) \times \mathbf{H}(\mathbf{m}) \times \mathbf{0 . 3 3}}{27}=\text { Vol. }\left(\mathbf{m}^{3}\right) \ldots \ldots(\text { Equ. } 2)
$$

Where $\mathrm{L}=$ length of the structure;

$\mathrm{W}=$ width of the structure;

$\mathrm{H}=$ height of the structure; and

0.33 represents the constant to account for the air space in the building"

\section{RESULTS AND FINDINGS}

Table 1 shows the satellite coordinates of the street containing the 13 roads under consideration as of 2011-2014 for the study.

Table 1: Satellite coordinates of streets 2011

\begin{tabular}{|c|c|c|c|}
\hline Roads & Name & Easting's & Northing's \\
\hline Road 1 & General Hospital-Tashan Dukku & $736090.61 \mathrm{~m}$ & $1139229.35 \mathrm{~m}$ \\
\hline Road 2 & Tashan Dukku-State University & $737261.73 \mathrm{~m}$ & $1139768.58 \mathrm{~m}$ \\
\hline Road 3 & ABSKG Road & $737779.57 \mathrm{~m}$ & $1138620.07 \mathrm{~m}$ \\
\hline Road 4 & Central pri. Sch.-Kasuwan doya & 737939.40m & $1137928.85 \mathrm{~m}$ \\
\hline Road 5 & Old post office-ABSKG & $737492.87 \mathrm{~m}$ & $1138074.33 \mathrm{~m}$ \\
\hline Road 6 & $\begin{array}{l}\text { Emir's palace-Idi praying } \\
\text { ground }\end{array}$ & $738474.96 \mathrm{~m}$ & $1138066.15 \mathrm{~m}$ \\
\hline Road 7 & Yelwan Bogo Road & $741232.67 \mathrm{~m}$ & $1136474.48 \mathrm{~m}$ \\
\hline Road 8 & (Alheri junction-yalen guruza) & $739774.54 \mathrm{~m}$ & $1136777.35 \mathrm{~m}$ \\
\hline Road 9 & Madaki - Burundi) & $738889.00 \mathrm{~m}$ & $1136090.00 \mathrm{~m}$ \\
\hline 4 & \multicolumn{3}{|c|}{$\begin{array}{l}\text { Article DOI: } 10.52589 / A J E N S R-S A F E X N K 8 \\
\text { DOI URL: https://doi.org/10.52589/AJENSR-SAFEXNK8 }\end{array}$} \\
\hline
\end{tabular}


African Journal of Environment and Natural Science Research

ISSN: 2689-9434

Volume 4, Issue 3, 2021 (pp. 1-11)

www.abjournals.org

\begin{tabular}{llll} 
Road10 & Nasarawo ring road & $741996.72 \mathrm{~m}$ & $1137267.35 \mathrm{~m}$ \\
Road 11 & Dogon Dibino & $737508.08 \mathrm{~m}$ & $1137691.15 \mathrm{~m}$ \\
Road 12 & Liberty-General hospital & $736425.04 \mathrm{~m}$ & $1137729.40 \mathrm{~m}$ \\
Road 13 & Miyetti-Union Bank & & \\
\hline
\end{tabular}

Source: Authors field work

Figure 1 shows that a total of 716 structures were marked for demolition along the roads in Lot 1. The findings revealed that structures along road no. 6 were the highest with 248 structures $(34.64 \%)$ and road no. 2 been the least with 8 structures.

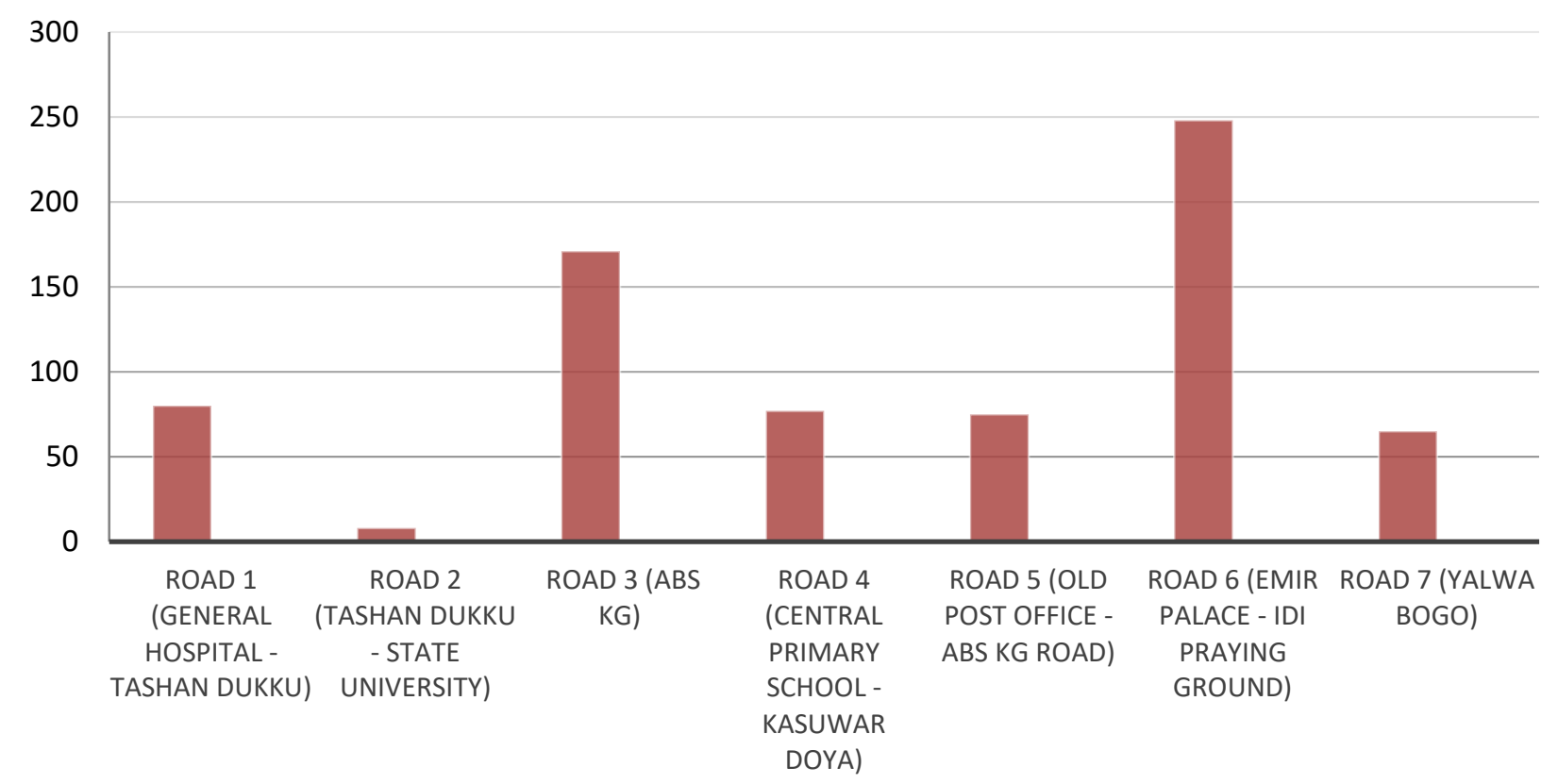

Figure 1: Lot 1, Number of structures marked for demolition along the roads

Source: Gombe state Ministry of Lands and Survey

Figure 2 shows that a total of 555 structures were marked for demolition along the roads in Lot 1 . The results revealed that road no. 2 was the highest with 178 structures $(32.07 \%)$ and structures along road no. 3 and 4 were the least with 22 structures each representing $3.96 \%$. 
African Journal of Environment and Natural Science Research

ISSN: 2689-9434

Volume 4, Issue 3, 2021 (pp. 1-11)

www.abjournals.org

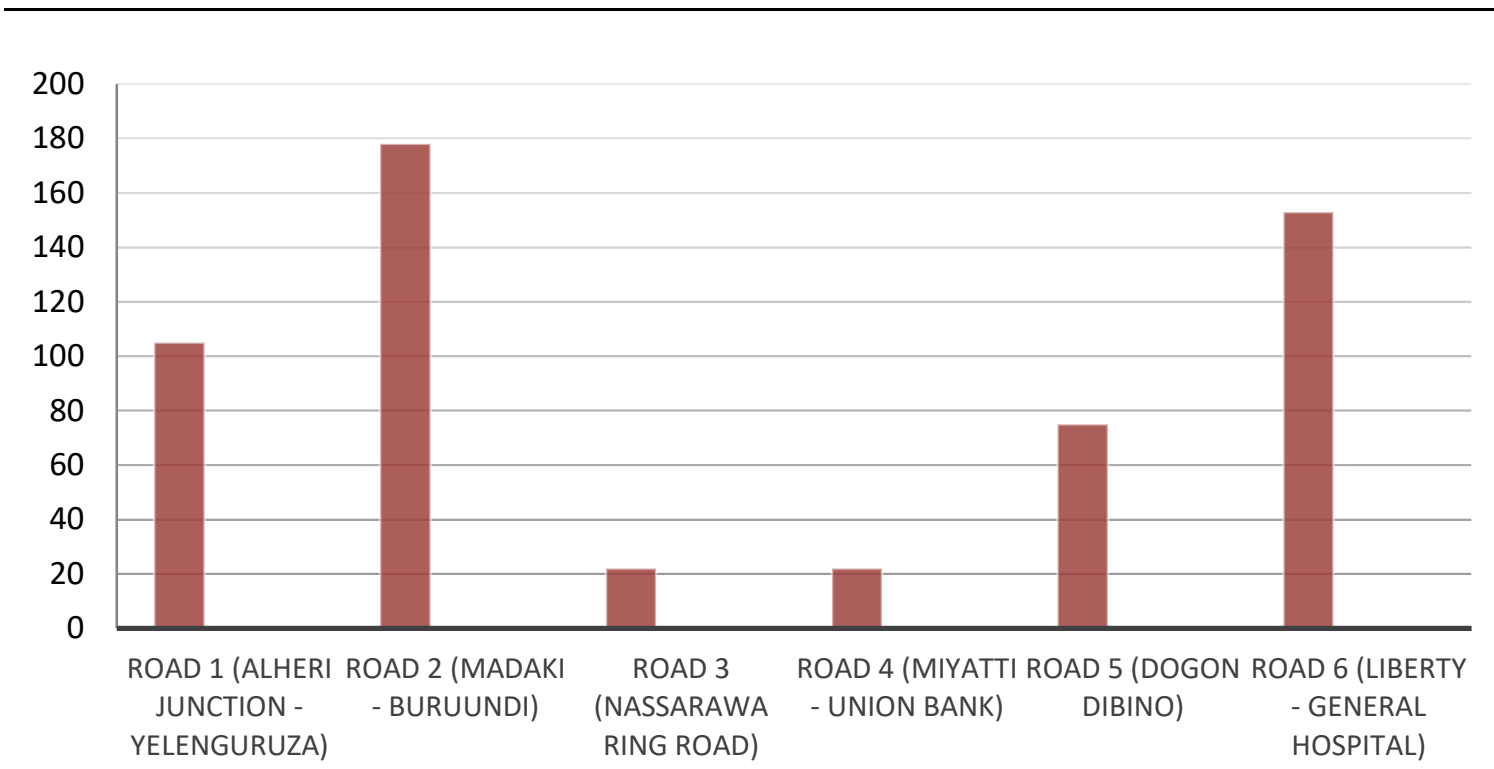

Figure 2: Lot 2, Number of structures marked for demolition along the roads

Source: Gombe State Ministry of Lands and Survey.

Plates 1, 2 and 3 show the various ongoing demolition activities of structures along the major roads with each plate showing concrete, sandcrete and clay representing the demolished materials respectively.

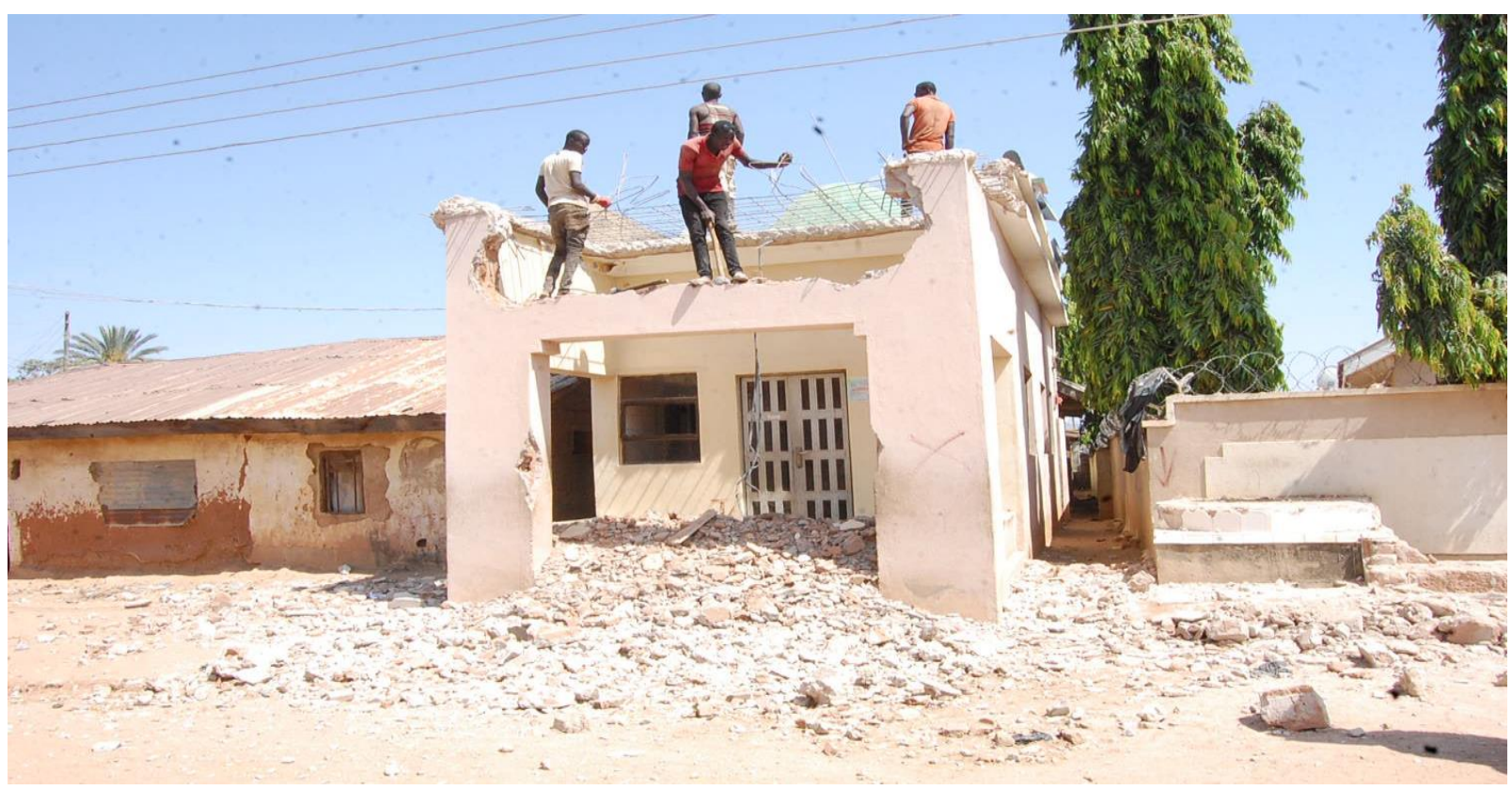

Plate 1: Demolition being carried out showing concrete debris on kasuwan doya road 4 in Lot 1

Source: Author's field work 
African Journal of Environment and Natural Science Research

ISSN: 2689-9434

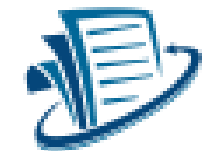

Volume 4, Issue 3, 2021 (pp. 1-11)

www.abjournals.org

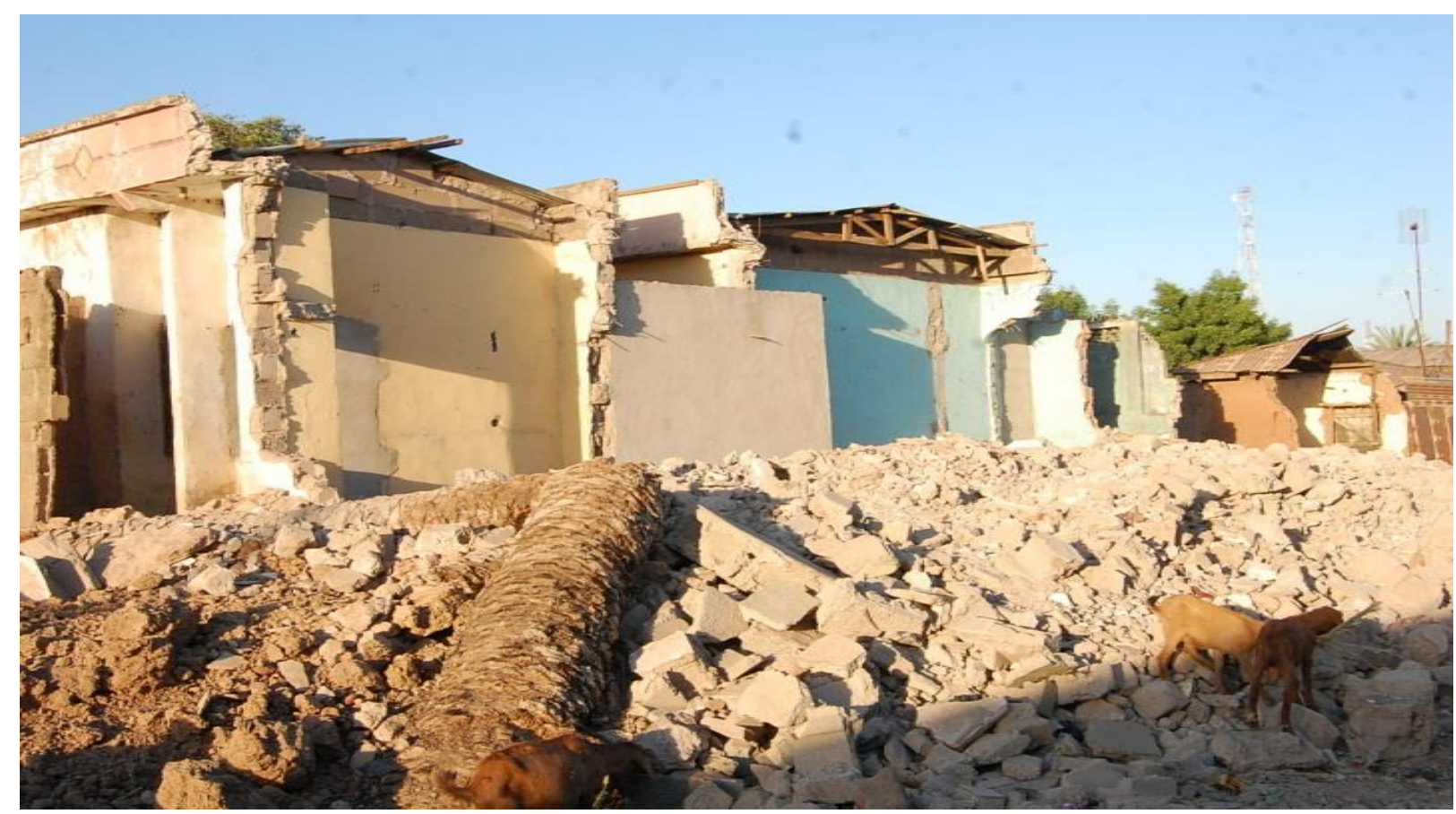

Plate 2: Sandcrete based demolition debris on Idi road 6 in Lot 1

Source: Author's Field work

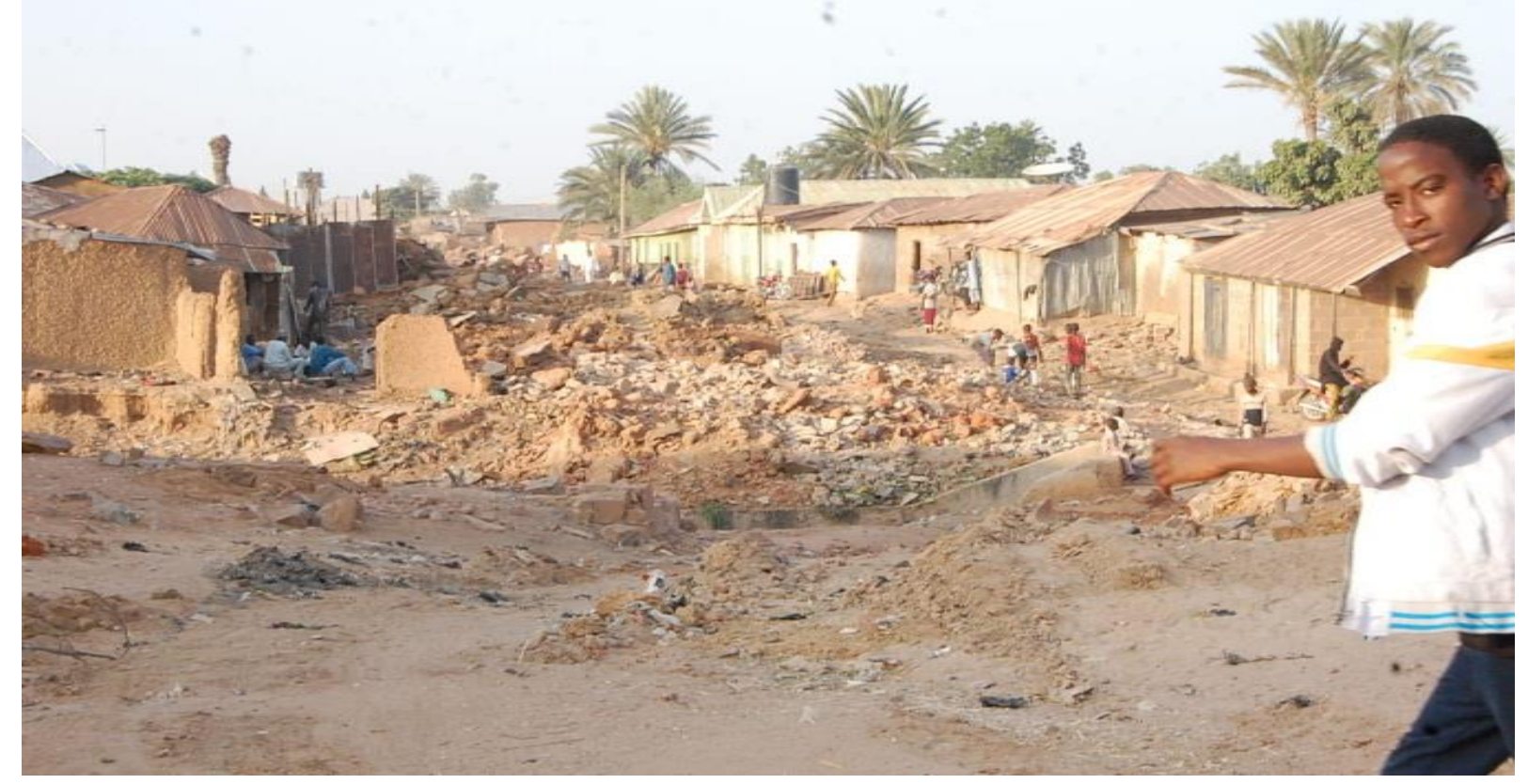

Plate 3: Clay based material from demolition on liberty-G/hospital road 1 in Lot 1

Source: Author's Field work 
Table 2 shows the volumetric composition of typical walling materials from demolition debris in Lot 1. Findings revealed that the total length of road was $8.33 \mathrm{~km}$, the total quantities of demolished debris generated was $70353.38 \mathrm{~m}^{3}$ with sandcrete been the major material with $34016.76 \mathrm{~m}^{3}$ representing $48.35 \%$ of demolished debris; Mud/Clay $25698.98 \mathrm{~m}^{3}(36.53 \%)$ and concrete $10637.64 \mathrm{~m}^{3}$ representing $15.12 \%$ of demolition debris generated.

Table 2: Volumetric Composition of Typical Walling Materials from Demolition debris in Lot 1

\begin{tabular}{|c|c|c|c|c|c|}
\hline \multirow[t]{2}{*}{$\mathbf{S} / \mathbf{n}$} & \multirow[t]{2}{*}{ Road } & \multirow{2}{*}{$\begin{array}{l}\text { Length } \\
(\mathrm{km})\end{array}$} & \multicolumn{3}{|c|}{ Quantity of Materials $\left(\mathbf{M}^{3}\right)$} \\
\hline & & & Concrete & Sandcrete & Mud/Clay \\
\hline 1 & $\begin{array}{l}\text { General Hospital- } \\
\text { Tashan Dukku Road }\end{array}$ & 2.30 & 1901.1735 & 346.205 & 305.487 \\
\hline 2 & $\begin{array}{l}\text { Tashan Dukku - Gombe } \\
\text { State University Road }\end{array}$ & 1.20 & 0 & 35.07 & 0 \\
\hline 3 & Bello Sabon Kudi Road & 1.00 & 2867.2632 & 9592.397 & 931.3731 \\
\hline 4 & $\begin{array}{l}\text { Cental Primary School } \\
\text { To Kasuwan Doya }\end{array}$ & 0.93 & 11.3481 & 4027.13 & 1.8 \\
\hline 5 & $\begin{array}{l}\text { Old Post Office To Bello } \\
\text { Sabon Kudi Road }\end{array}$ & 0.41 & 4652.109 & 9104.5728 & 13756.6818 \\
\hline 6 & $\begin{array}{l}\text { Emir's Palace Round } \\
\text { About-Idi Praying } \\
\text { Ground }\end{array}$ & 1.40 & 221.5026 & 4713.6805 & 6120.4824 \\
\hline 7 & Yelwan Bogo Road & 1.10 & 984.24 & 6197.70 & 4583.16 \\
\hline & Total & 8.33 & 10637.64 & 34016.76 & 25698.98 \\
\hline
\end{tabular}

Source: Author

Table 3 shows the volumetric composition of typical walling materials from demolition debris in Lot 2. Findings revealed that the total length of road was $15.04 \mathrm{~km}$, the total quantities of demolished debris generated was $59640.19 \mathrm{~m}^{3}$ with sandcrete been the major material with $44371.06 \mathrm{~m}^{3}$ representing $74.40 \%$ of demolished debris; Clay/Mud $12900.29 \mathrm{~m}^{3}$ $(21.63 \%)$ and concrete $2368.84 \mathrm{~m}^{3}$ representing the least with $3.97 \%$ of demolition debris generated. 
Table 3: Volumetric Composition of Typical Walling Materials from Demolition debris in Lot 2

\begin{tabular}{|c|c|c|c|c|c|}
\hline \multirow[t]{2}{*}{$\mathbf{S} / \mathbf{n}$} & \multirow[t]{2}{*}{ Road } & \multirow{2}{*}{$\begin{array}{l}\text { Length } \\
(\mathbf{k m})\end{array}$} & \multicolumn{3}{|c|}{ Quantity of Materials $\left(\mathbf{M}^{3}\right)$} \\
\hline & & & Concrete & Sandcrete & Mud/Clay \\
\hline 1 & $\begin{array}{l}\text { Alheri Juncton - } \\
\text { Yalengnguruza }\end{array}$ & 8.0 & 1099.16 & 9543.03 & 1961.86 \\
\hline 2 & $\begin{array}{l}\text { Madaki To Barunde Bye } \\
\text { Pass Road }\end{array}$ & 2.1 & 1269.68 & 15953.83 & 5693.00 \\
\hline 3 & Nasarawo Ring Road & 2.8 & 0.00 & 746.70 & 3060.00 \\
\hline 4 & $\begin{array}{l}\text { Miyetti Junction To } \\
\text { Intersect Union Bank }\end{array}$ & 0.87 & 0.00 & 41.28 & 0.00 \\
\hline 5 & Dogon Dabino Road & 0.64 & 0.00 & 4550.17 & 523.80 \\
\hline 6 & $\begin{array}{l}\text { Liberty Junction To } \\
\text { General Hospital Road }\end{array}$ & 0.63 & 0.00 & 13536.05 & 1661.63 \\
\hline
\end{tabular}

\begin{tabular}{rrrrr}
\hline Total & $\mathbf{1 5 . 0 4}$ & $\mathbf{2 3 6 8 . 8 4}$ & $\mathbf{4 4 3 7 1 . 0 6}$ & $\mathbf{1 2 9 0 0 . 2 9}$ \\
\hline
\end{tabular}

Source: Author

\section{DISCUSSION}

Demolished debris (DD) composed of Concrete, Sandcrete and Clay in all streets locations in Gombe city the study area. Quantities of materials generated were derived along the lengths of road $(23.37 \mathrm{~km})$. A total of 1271 structures were evaluated for partial or full demolition on lot 1 and lot 2 for street widening or to pave way for new road construction in the study. Data showed from both lots $1 \& 2$ a total volume of $129,993.57 \mathrm{~m}^{3}$ of Debris generated and composed of $10.00 \%$ Concrete, $60.30 \%$ Sandcrete and $29.69 \%$ clay/mud. The finding was in agreement with (Tunde \& Jinadu, 1997), that infrastructural development such as roads within the urban built environment has seen the demolition of thousands of buildings in Nigeria. Wood, concrete, brick and other masonry typically constitute more than $60 \%$ of residential and $80 \%$ of non-residential demolition debris (FEMA, 2010). In addition, (USEPA, 1998) reported that demolition debris constitute $34 \%$ of waste generated from residential and 58\% from non-residential areas. Demolition debris (DD) is the largest amounts of waste (Collins, 2011) in the solid waste stream, and posed a real threat to all countries. Its composition is not unique and depends on the techniques of construction, type of building, country and many other factors. 


\section{CONCLUSION AND RECOMMENDATION}

Basically, as the saying goes; data is not widely available for construction and demolition waste in many countries around the globe, efforts must be made to provide workable data to harness the waste littered in the environment. In recent times, infrastructural development in Nigeria's major cities has led to the increase in road construction activities most noticeably in the state capitals and local government headquarters. The objective of this study is to determine the volumetric composition of generated demolition debris in Gombe City with a view to know the potential quantities available for re-use. Hence, a total volume of $129993.57 \mathrm{~m}^{3}$ of Demolition Debris was generated in Gombe city and composed of $10.00 \%$ Concrete, $60.30 \%$ Sandcrete and $29.69 \%$ clay/mud. As such, there exist a huge quantity of building demolished debris from street widening and new road construction in the Gombe city which can be put back in to re-use and that will go a long way in reducing the adverse effects on the environment due to excessive exploitation for new material. Furthermore, extends the lifecycle and complete the close loop principle thereby, the ends of Architecture define the beginning of a new discipline in the $21^{\text {st }}$ century.

\section{REFERENCES}

Agamutu, P. (2008), Challenges in Sustainable Management of Construction and Demolition Waste; Waste Management Resources, 26, 491 American Plastic Council 1997

Akaninyene, A.U., (2012), Recycling Demolition Waste Sandcrete Blocks as Aggregate in Concrete: ARFOR Journal of Engineering and Applied Sciences 7(9) Sept, 2012 ISSN 1819-6608.

Asif, H., and Matouq, M.A.(2013), Utilization of Demolition Concrete Waste for New Construction; World Academy of Science, Engineering and Technology, (7), 2013-0123, international science index; 7(1), 2013 waste.org/published/8588.

Calhoun, A.B. (2012), Impact of Construction and Demolition Debris Recovery Facilities on Job Creation and Environment in Florida; unpublished thesis submitted to the Eradiate School of the University of Florida.

Collins, J. (2011). Construction and Demolition Waste Recycling; A Literature Review. Dalhousie University's Office of Sustainability Commission on Environment and Development, Oxford University Press, Oxford.

Daily trust (March 21, 2016). www.dailytrust.com

El Haggar, S. (2007), Sustainable Industrial Design and Waste Management: Cradle-to-Grave for Sustainable Development. Academic Press Cambridge, Massachusetts

EPA US Environment Protection Agency (2009), Recommending Solid Waste as a Renewable Energy Feedstock; Environmental and Energy Study Institute, July.

Falaki, A.A., Akanghe, J.A \& Ayinde, O.E (2013). Analysis of Climate Change and Rural Farmers' Perception in North Central Nigeria, Journal of human Ecology 43(2) 13-140

FEMA Debris Estimating Field Guide; FEMA 321/September 2010

National Population Commission [NPC] (2006). Population census 2006. www.npc.gov.ng.

Nunes, K.R.A., Miller, C.F., valle, R. and Neves. C. (2006), Evaluation of Investment in Recycling Centers for Construction and Demolition Wastes in Brazilian Municipalities; science direct waste management xxx (2006) available online at www.sceicnedirect.com. 
Ofori, G. (2010). Challenges of construction industries in developing countries: lessons from various countries http//:www.trid.trb.org/view/doc access date $2 / 3 / 2015$

Richard, D. and Micheal, E.T. (2006), Demolitions Hand Book of Professional Practice. Update 2006.

Tunde, A. \& Jinadu, A.M. (1997), Forced Eviction and Forced Relocation in Nigeria: the Experience of those Evicted from Maroko; environmental and urbanization in Nigeria; African Journal of Environmental Science and Technology Vol. 5(3), pp. 241246 March. 9(2) October 1997. Downloaded from sagepub.com August 9, 2015

Uher, T.E (1999). Absolute indicator of sustainable construction. Proceedings of COBRA 1999. RICS Research foundation. RICS, London, pp. 234-253

United State Environmental Protection Agency [USEPA] (1988)

Vilas, M and Guiliberto, B. (2007), Construction and Demolition Waste Management: Current Practices in Asia; Proceeding of International Conference on Sustainable Solid Waste Management, 5-7 Sept. 2007 Chanrai, Indian Pp 97-104. 